УДК 811.111'232-112

DOI https://doi.org/10.26661/2414-1135-2021-81-1-12

\title{
ЕВОЛЮЦІЯ КОНЦЕПТУ ЕРІDЕМІС В ІСТОРИЧНОМУ РОЗВИТКУ СУСПІЛЬСТВА
}

\author{
Гахарія К. В. \\ аспірантка кафедри англійської філологї \\ Запорізький національний університет \\ вул. Жуковського, 66, Запоріжжя, Україна \\ orcid.org/0000-0003-3180-5859 \\ karinavramenko@gmail.com
}

\begin{abstract}
Ключові слова: кониепт, EPIDEMIC, історичні трансформації, конотації, етимологія.
\end{abstract}

Стаття пропонує дослідження базових трансформацій концепту EPIDEMIC і набуття ним нових смислових відтінків в історичному розвитку людства.

Актуальність пояснюється необхідністю перегляду особливостей функціонування концепту EPIDEMIC у колективній свідомості через COVID-19. Аналіз останніх досліджень показав, що тема набула популярності у зв'язку з пандемією, але дослідники звертаються радше до відображення коронавірусу в сучасних дискурсах, мемотворчості й неологізмів цього періоду. Значна увага зосереджена саме на концептах PANDEMIC, CORONAVIRUS.

Метою статті $\epsilon$ спроба аналізу еволюційних змін концепту EPIDEMIC у зв'язку з історичним розвитком суспільства та набуттям ним нових смислових відтінків. У роботі подається огляд різних інтерпретацій і підходів до розуміння явища епідемії, представлений медиками, науковцями, філософами, істориками, теологами, політиками й митцями різних епох, починаючи від найпершого значення слова «епідемія» до його сучасного тлумачення у словниках. У статті згадуються (або процитовані) такі історичні постаті: Гомер, Гіппократ, Фукідід, Прокопій Кесарійський, Генрі Ланкастерський, Джованні Боккаччо та інші. Таке дослідження дало змогу авторці якнайповніше наблизитися до узагальненого розуміння історичного розвитку та еволюції концепту EPIDEMIC, простежити взаємозв'язок між часово-просторовим контекстом і сприйняттям вищезгаданого концепту, а також представити власне бачення щодо особливостей еволюції концепту в ході історичного розвитку суспільства.

Зазначимо, що в результаті стаття відображає спробу авторки провести аналіз історичних віх функціонування слова «епідемія», остаточного мовного оформлення цього концепту, а також підкреслити зміни, які відбувалися в колективній свідомості, пов'язані з епідеміями. Практичне значення статті в тому, що вона розпочинає потенційно насичений для досліджень пласт філологічних розвідок, який можна заглибити в подальших роботах, акцентуючи увагу на функціонуванні концепту EPIDEMIC у різних часових рамках, країнах, дискурсах тощо. 


\title{
EVOLUTION OF THE CONCEPT EPIDEMIC IN HISTORICAL DEVELOPMENT OF SOCIETY
}

\author{
Hakhariia K. V. \\ Postgraduate Student at the Department of English Philology \\ Zaporizhzhia National University \\ Zhukovskoho str., 66, Zaporizhzhia, Ukraine \\ orcid.org/0000-0003-3180-5859 \\ karinavramenko@gmail.com
}

Key words: concept, EPIDEMIC, historical transformations, connotations, etymology.

\begin{abstract}
This article provides a study of the basic transformations of the concept of EPIDEMIC and its connotations in the historical development of mankind.

The relevance is explained by the need to rethink of the features of the concept of EPIDEMIC in the collective consciousness caused by COVID-19. An analysis of recent research has shown that the topic has gained popularity in connection with the pandemic, but researchers prefer to turn to the reflection of the coronavirus in modern discourses, creation of memes and neologisms of this period. Most of the attention is focused on the concepts of PANDEMIC, CORONAVIRUS. At the same time, the semantically similar concept of EPIDEMIC remains out of the attention of scientists.

The aim of the article is to try to analyze the evolutionary changes of the EPIDEMIC concept in connection with the historical development of society. The paper provides an overview of different approaches to understanding the phenomenon of the epidemic, presented by scientists, philosophers, historians, theologians, politicians and artists of different eras, from the first meaning of the word "epidemic" to its modern interpretation in dictionaries. The article mentions (or quotes) the following historical figures: Homer, Hippocrates, Thucydides, Procopius of Caesarea, Henry of Lancaster, Giovanni Boccaccio and others. This study allowed the author to get as close as possible to a generalized understanding of the historical development and evolution of the EPIDEMIC concept and to present his own vision of the evolution of the concept during historical development.

As a result, the article reflects the author's attempt to conduct an analysis of the historical milestones of the word "epidemic", the linguistic expression of this concept, as well as to emphasize the changes in the collective consciousness associated with epidemics. The practical significance of the article is that it begins a potentially rich layer of philological research, which can be deepened in further work, focusing on the functioning of the concept of EPIDEMIC in different time frames, countries, discourses, etc.
\end{abstract}

Постановка проблеми. У зв'язку з викликами, що постали перед людством через COVID-19, у всіх галузях науки значного поширення набули дослідження, пов'язані з хворобами та здоров'ям населення. Безсумнівно, передусім увага зосереджена на медичних і біологічних дослідженнях, а також на простеженні впливу пандемії на економіку, безпеку й освіту. Утім епідемії та пандемії як глобальні проблеми неможливо повною мірою усвідомити (а отже, і вирішити) без відповідних розвідок у царині філології, зокрема тих, що досліджують історію формування концептів EPIDEMIC, PANDEMIC, CORONAVIRUS тощо.

Історичні трансформації й відповідна еволюція концептів у різні віхи розвитку суспільства та нау- ково-технічного прогресу дають змогу не тільки осмислити роль і функції тих або інших концептів в історичному розвитку людства, а й з'ясувати їх вплив на свідомість, культуру та навіть на загальну картину світу. Наріжним каменем дослідження $\epsilon$ концепт EPIDEMIC, актуалізований у зв'язку 3 глобальними світовими викликами. Утім, незважаючи на очевидну актуальність і безпосередній вплив на формування світового порядку денного, у вітчизняному науковому дискурсі поки що бракує вичерпних досліджень, що були б присвячені концептам EPIDEMIC, PANDEMIC, VIRUS i ïx походженню і трансформаціям.

Аналіз останніх публікацій показав, що тема привертає увагу мовознавців у зв' язку з COVID-19. 
Так, у 2020 році виникає чимало публікацій, пов'язаних із концептом CORONAVIRUS, його вербалізацією та проявами в медійному дискурсі, лексичними інноваціями, створеними у зв'язку 3 пандемією коронавірусу тощо (зокрема роботи україномовних i російськомовних дослідників-Н. Долусової, С. Жаботинської, В. Катерміної, К. Красницької, Н. Степанюк, К. Яченко; зарубіжних - Z. Hu, S. Karami, Q. Li, Ö. Mahmut, Z. Yang, A. Zhang та інших). В англомовному науковому дискурсі наявні розвідки, присвячені концепту VIRUS, PANDEMIC, їх застосуванню та змінам у ході історії, а також особливостям функціонування (наукові роботи R. Cardilli, V. T. Covello, J. Clemens, M.E. Hanson, V. Langholf, A. Mitropoulos etc.). Утім малодослідженими або взагалі не дослідженими залишаються питання еволюції концептів категорії медично-епідеміологічного дискурсу, що, на нашу думку, потребує висвітлення.

Метою статті $\epsilon$ спроба дослідити еволюцію змісту та сприйняття концепту EPIDEMIC у контексті міжгалузевих розвідок (включаючи філологію, біологію, право, медицину, історію, філософію, мистецтво та психологію тощо), а також представити хронологічну систему історичних трансформацій концепту.

Реалізація визначеної мети статті передбачає виконання таких завдань: 1. Розглянути основні історичні підходи до розуміння та сприйняття концепту EPIDEMIC. 2. Проаналізувати сучасне значення концепту EPIDEMIC.

Виклад основного матеріалу дослідження. Концепт EPIDEMIC $\epsilon$ складником медично-епідеміологічного дискурсу. Він представлений у більшості культур і мов світу через належність до професійного лексикону медиків і біологів, утім не обмежується лише цією сферою застосування. Сьогодні помітно, що концепти EPIDEMIC, PANDEMIC, VIRUS etc. набувають значного поширення в історичному, медійному, художньому дискурсах; навіть у побутовій сфері. Частота їх уживання і транслювання в різних сфеpax людського буття можна пояснити глобалізацією сучасного світу, екологічними проблемами, які стають причинами поширення захворювань, економічним розвитком і його впливом на модернізацію медицини, доступністю інформації щодо здоров'я та хвороб населення, а також популярністю соціальних мереж і блогів, у яких експерти (медики, біологи, науковці) можуть поширювати знання про ті або інші аспекти фізичного та ментального здоров'я людей.

Важко заперечити, що погляди людей на епідемії трансформувалися впродовж історії й прямо корелювализ науково-технічнимпрогресом, досягненнями у сфері інноваційної медицини, а також iз цивілізаційним розвитком суспільства загалом.
Згідно з дослідженням П.М. Мартін та Е. Мартін-Гранел, «термін «епідемія» (від грецького epi [on] плюс demos [люди]), уперше використаний Гомером, набув свого медичного значення, коли Гіппократ використав його як заголовок для одного зі своїх відомих трактатів» [8]. У період до Гіппократа це слово використовувалося радше в політичному та філософському контексті, аніж медичному. Дослідник А. Віллас Боас зазначив, що цей концепт зазнав семантичної еволюції. Початкове його осмислення стосувалося народу та використовувалося письменниками й ораторами на позначення «чогось, що трапляється в народі» («as something that happens "in the people" [epi demos]») [10]. Автор стверджує, що в такому значенні слово проіснувало століття і його використовували Платон, Теетет, Симпозіум, Парменід, Арістотель, Ксенофонт, Фукідід, Арістофан, Софокл. Із контексту запропонованих науковцями цитат давньогрецьких текстів розуміємо, що концепт EPIDEMIC стосувався тем внутрішньої та зовнішньої політики, репутації відомих осіб «у народі» й навіть громадянської війни як такої, що відбувається «серед народу» [8; 10].

Як уже згадано раніше, медичного значення концепт EPIDEMIC набув уже після того, як він був використаний античним лікарем Гіппократом. У першій книзі «Епідемії» він дає характеристику кожному сезону, а потім наводить опис характерних для кожної пори року хвороб і їх симптомів. Значну увагу медик приділяе конкретним випадкам і пацієнтам, описує їх зараження, симптоми та наслідки від хвороб [6]. Примітно, що серед дослідників (зокрема позиції 8,10 у списку літератури) ще і досі не вирішене питання походження та передумов цієї смислової трансформації слова. Без відповіді залишається й питання, чому Гіппократ використав у назві трактату слово «епідемії». Так, згідно 3 історичними дослідженнями [8], на той час були поширеними терміни, що відповідали хворобам, проблемам здоров'я і руйнації тіла, утім слово «епідемія» для їх позначення не використовували.

Подальші смислові навантаження, яких набув концепт, додали йому більш конкретного та вузького значення, а також були прямо пов'язані з історичним контекстом i масовими зараженнями. Першим достовірно історично відомим випадком епідемії була чума в Афінах, яку описав у роботі Фукідід. В «Історії Пелопоннеської війни» він присвятив 25 глав цій епідемії, детально описуючи симптоматику чуми, іiі розповсюдження та причини виникнення, а також соціальні й економічні наслідки. Однак саме поняття «епідемія» в роботі Фукідід не використовував [4]. Цей період можна вважати початком формування в суспільній свідомості концепту EPIDEMIC як пов'язаного із масо- 
вим і швидким поширенням хвороби серед населення. Як бачимо, цей етимологічний шар уже охоплює медичне значення epidemos i входить у змістовий мінімум концепту EPIDEMIC.

Перша зареєстрована пандемія (світова епідемія) - Юстиніанова чума - закріпила в колективному несвідомому небезпеку та смертоносність цього явища, остаточно змістила сприйняття концепту EPIDEMIC у негативний полюс. Більше того, у цей період він набуває асоціацій із невідворотністю, фатальністю та повною руйнацією. Так, письменник Прокопій Кесарійський, ставши свідком чуми, писав: «Від чуми не було спасіння людини, де 6 вона не жила $<\ldots>$ багато будинків спорожніли $<\ldots>$ мало кого було можна зустріти за роботою» [2, с. 106].

Наступний етап в еволюції цього концепту відбувся в добу високого та пізнього Середньовіччя, має зв'язок із християнством та епідемією чуми. Хвороби, як й епідемії, у цю епоху найчастіше трактувалися як покарання за гріхи та зображалися метафорично. Одним із яскравих прикладів напівметафоричного сприйняття концепту EPIDEMIC $\epsilon$ трактат XIV століття «Свята медицина» (Le Livre de Seyntz Medicines (The Book of Holy Medicine)), написана Генрі Ланкастерським. У цій роботі «міститься найбільш широко відоме використання медичних метафор та образів для опису релігійного досвіду» («it contains the most extensive known use of medical metaphors and imagery to describe religious experience») [11]. Цей твір, написаний у розпал епідемії Чорної смерті, хоч і є автобіографічним і присвячений визнанню гріхів автора, спрямований на найширшу аудиторію та закликає покаятися всім читачам і звернутися для захисту від чуми найперше до «лікарів душі», а вже потім до «лікарів тіла»: «Most sweet Lord, have mercy on me and give me grace that I might with my tongue heal the foul wound of my mouth, and with my tongue clean it of the filth that is there, that is, by confessing the filthy sins of my mouth and all the others, by true confession, with heartfelt sorrow» [13].

Поряд із цим у період Раннього Відродження розпочинаються й перші спроби раціоналізувати містично-релігійний образний і значущий складник концепту EPIDEMIC. Наприклад, письменник Дж. Боккаччо зі скептицизмом і певним гумором пояснює смертоносність епідемії не ії надприродним походженням, а звичайним нерозумінням лікарів і шарлатанів сутності проблеми: «Ніякі поради доктора не помагали од сього помору, ніякі ліки не ставали в пригоді: чи то вже така була натура хвороби, чи неуки-гоїтелі (а тоді, крім учених медиків, порозводилося було багато лікарів і лікарок, що зроду й не нюхали медицини), не мігши знати, у чім сила недуги, не вміли прибрати на неї спо- собу» [1, с. 4]. Тоді ж активізуються дослідницькі прагнення лікарів і вчених, спрямовані на захист здоров’я та певну раціоналізацію людських уявлень про епідемії. Так, в епоху чуми з'являється 281 «чумний трактат», кожен із яких присвячений спробам зрозуміти причини епідемії та рекомендаціям щодо ефективного лікування тощо [12].

Чергові етапи еволюції терміна описані в дослідженні П.М. Мартіна та Е. Мартін-Гранел: «Термін «уріdime» в середньовічній французькій мові бере свій початок із цих латинських слів, далі він став «еруdime» в 14 столітті, «еріdimie» в 17 столітті, а потім «еріdémie» у 18 столітті. Лише через 22 століття після Гіппократа, у другій половині XIX століття, терміни «épidémiologie» (1855), «épidémiologique» (1878) та «épidémiologiste» (1896) з'явилися у французькій мові» [8]. Автори стверджують, що в англійській мові схожі трансформації відбувалися майже водночас зі змінами у французькій. Додамо, що друга половина XIX століття - визначний етап не тільки для епідеміології як медичної галузі, а й для розуміння терміна «епідемія» та концепту EPIDEMIC загалом. Він пов’язаний із постатями Л. Пастера, Р. Коха, А. Левенгука, Дж. Сноу та їхніми відкриттями, які остаточно обгрунтували раціональний підхід до розуміння концепту EPIDEMIC, затвердили його функціонування в медичному дискурсі та додали нових смислових відтінків до значення.

Словник-тезаурус XXI століття пропонує такі синоніми для лексеми «epidemic»: «widespread catching, communicable, contagious, endemic, general, infectious, pandemic, prevailing, prevalent, rampant, rife, sweeping, wide-ranging; widespread disease contagion, endemic, growth, outbreak, pest, pestilence, plague, rash, scourge, spread, upsurge, wave, what's going around» [9]. B Encyclopaedia Britannica знаходимо сучасну дефініцію лексеми: «Epidemic, an occurrence of disease that is temporarily of high prevalence. $<\ldots>$ The rise and decline in epidemic prevalence of an infectious disease is a probability phenomenon dependent upon transfer of an effective dose of the infectious agent from an infected individual to a susceptible one» [3]. Звернення до лексикографічних фактів дає нам можливість дослідити як основну, так і внутрішню форми концепту, адже в цих синонімах ми простежуємо як і загальне, відкладене в колективній свідомості сприйняття концепту EPIDEMIC, так і те, що не доступне більшості людям, а відкрите для розуміння лише фахівцям у певних сферах (медикам, біологам, історикам і лінгвістам).

Отже, отримані факти підтверджують припущення авторки, що концепт EPIDEMIC зазнав численних історичних трансформацій. Розвиток лексичного значення слова «епідемія», яке номінує досліджуваний нами концепт, проходило шляхом 
диференціації й ускладнення змісту за рахунок нашарування додаткових смислів і відтінків значень. Останні, у свою чергу, пов'язані з релігією, науково-технічним прогресом, розвитком медицини та впливом спалахів масштабних світових епідемій на колективну свідомість населення світу.

Що стосується сучасної англійської мови, то сьогодні концепт EPIDEMIC має переважно значення великого спалаху певної хвороби, використовується здебільшого в медичному дискурсі та найчастіше асоціюється в людей саме зі сферою здоров'я.

3'ясовано, що первинне значення слова «еріdemic» відрізнялося від того, яке існує сьогодні. Уперше використане Гомером, а потім іншими давньогрецькими письменниками й філософами, воно означало щось поширене в народі або в межах певної країни. Гіппократ став першим, хто використав слово «епідемія» в медичному контексті. Деякі смислові навантаження та відтінки додавалися, інші зникали, але у зв'язку з постійним активним прогресом людства в семантиці стало переважати розуміння епідемії як хвороби, що швидко й активно розповсюджується, зумовлена епідемічним штамом. Саме через розвиток біологічних досліджень, наукових відкриттів i покращення стану медицини концепт EPIDEMIC утратив або мінімізував свою релігійно-містичний складник. У сучасному світі багатошарова структура концепту EPIDEMIC включає не лише базові параметри (поширеність, масовість), а й образні та асоціативні, що пояснюється відбитком історичного розвитку людства на колективній свідомості.

Ми вважаємо перспективним подальше дослідження ролі й місця концепту EPIDEMIC в англомовній картині світу.

\section{ЛІТЕРАТУРА}

1. Боккаччо Дж. Декамерон / пер. 3 італ. М. Лукаша. Харків : Фоліо, 2004.

2. Даниэл М. Тайные тропы носителей смерти / пер. с чеш. Е.А. Егорова ; под ред. Б.Л. Черкасского. Москва : Прогресс, 1990.

3. Britannica T. Editors of Encyclopaedia Epidemic. Encyclopedia Britannica. 2020. URL: https:// www.britannica.com/science/epidemic (accessed 10 March 2021).

4. Cohn S.K. Epidemics: hate and compassion from the plague of Athens to AIDS. 2018. URL: Retrieved from: https://bit.ly/3edVf3G (accessed 10 March 2021).

5. Grigsby B.L. Pestilence in Medieval and Early Modern English Literature. New York : Routledge, 2004.

6. Hippocrates. Of the Epidemics / Transl. by F. Adams. (n.d.) HTML anthology. URL: http://classics.mit.edu/Hippocrates/epidemics. html (accessed 10 March 2021).
7. List of etymologies of words in $90+$ languages (n.d.). URL: http://www.ezglot.com/etymologies.php (accessed 10 March 2021).

8. Martin P., Martin-Granel E. 2,500-Year Evolution of the Term Epidemic. Emerging infectious diseases.2006. Vol.6.№ 12.P.976-80.URL:10.3201/ eid1206.051263 (accessed 10 March 2021).

9. Roget's 21st Century Thesaurus, 3rd edition. New York : A Delta Book, 2005.

10. Villas Boas A. Spirituality and Health in Pandemic Times: Lessons from the Ancient Wisdom. Religions. 2020. Vol. 11. № 583. URL: https:// doi.org/10.3390/rel11110583 (accessed 10 March 2021).

11. Virtual Mentor. 2006. Vol.4.№8.P.256-260.URL: https://doi: $10.1001 /$ virtualmentor.2006.8.4.mhst1-0604 (accessed 10 March 2021).

12. Winslow C., Duran-Reynals M. (1948) Jacme D'Agramont and the first of the plague tractates. Bulletin of the History of Medicine. 1948. Vol. 6. № 22. P. 747-765. URL: http://www.jstor.org/stable/44442234 (accessed 10 March 2021).

13. Yoshikawa N.K. Holy medicine and diseases of the soul: Henry of Lancaster and Le livre de seyntz medicines. Medical history. 2009. Vol. 3. № 53. Р. 397-414.

\section{REFERENCES}

1. Boccaccio G. Dekameron. (2004) / Per. z Ital. M. Lukasha [Dekameron / Transl. from Ital. by M. Lukash]. Kharkiv: Folio (in Ukrainian).

2. Daniel M. (2010) Taynyie tropyi nositeley smerti / Per. s chesh. E. Egorova; Pod red. B. Cherkasskogo [The secret paths of death carriers / Transl. from Czech by E. Egorov; Edited by B. Cherkasskyi]. Moscow: Progress (in Russian).

3. Britannica, T. Editors of Encyclopaedia Epidemic. Encyclopedia Britannica. (2020) Retrieved from: https://www.britannica.com/science/epidemic (accessed 10 March 2021).

4. Cohn, S. K. Epidemics: hate and compassion from the plague of Athens to AIDS. (2018) Retrieved from: https://bit.ly/3edVf3G (accessed 10 March 2021).

5. Grigsby, B. L. Pestilence in Medieval and Early Modern English Literature. (2004) New York: Routledge.

6. Hippocrates. Of the Epidemics / Transl. by F. Adams. (n.d.) HTML anthology. Retrieved from: http://classics.mit.edu/Hippocrates/epidemics.html (accessed 10 March 2021).

7. List of etymologies of words in $90+$ languages. (n.d.) Retrieved from: http://www.ezglot.com/ etymologies.php (accessed 10 March 2021).

8. Martin, P., Martin-Granel, E. (2006) 2,500-Year Evolution of the Term Epidemic. Emerging infectious diseases, vol. 6, no. 12, pp. 976-80. 
Retrieved from: 10.3201/eid1206.051263 (accessed 10 March 2021).

9. Roget's 21st Century Thesaurus, 3rd edition. (2005) New York: A Delta Book.

10. Villas Boas, A. Spirituality and Health in Pandemic Times: Lessons from the Ancient Wisdom. (2020) Religions, vol. 11, no. 583. Retrieved from: https://doi.org/10.3390/rel11110583 (accessed 10 March 2021).

11. Virtual Mentor. (2006) vol. 4, no. 8, pp. 256-260. Retrieved from: https://doi: 10.1001/ virtualmentor.2006.8.4.mhst1-0604 (accessed 10 March 2021).

12. Winslow, C., \& Duran-Reynals, M. (1948) Jacme D'Agramont and the first of the plague tractates. Bulletin of the History of Medicine, vol. 6, no. 22, pp. 747-765. Retrieved from: http://www. jstor.org/stable/44442234(accessed 10 March2021).

13. Yoshikawa, N. K. (2009) Holy medicine and diseases of the soul: Henry of Lancaster and Le livre de seyntz medicines. Medical history, vol. 3, no. 53, pp. 397-414. 